ISBN 978-93-86878-06-9

8th International Conference on Literature, Languages, Humanities and Interdisciplinary Studies

(LLHIS-17)

Kuala Lumpur (Malaysia) Dec. 14-15, 2017

\title{
LOUD : Authoritative Parenting Style to Minimalize Adolescent Delinquency
}

\author{
Dini Trijayati \\ Department of Family and Consumer Science, Faculty of Human Ecology, \\ Bogor Agricultural University, Indonesia
}

\begin{abstract}
The level of adolescent delinquency in Indonesia is increasing every year in both urban and rural areas. This becomes an urgency to concern about spiritual mental revolution at the adolescent level that can be done with the main indicator, that of parenting. The purpose of this paper is to identify parenting style and adolescent delinquency in Indonesia, and to describe the concept of LOUD authoritative parenting style. Furthermore, literature studies about historical data of adolescent delinquency and parenting styles of children in Indonesia, and the formulation of the concept of LOUD authoritative parenting style with POAC analysis is a method of writing. There is a diversity of parenting styles that can be grouped into four categories, namely neglectful, permissive, authoritarian, and authoritative. Among the four parenting styles identified in Indonesia, authoritative parenting style is the best category to apply that can be minimize adolescent delinquency. LOUD authoritative parenting style includes four inputs in parenting to the adolescent, namely loving, organizing, understanding, and developing. Furthermore, POAC is useful as a step in realizing parenting style based LOUD concepts (loving, organizing, understanding, and developing). The essence of LOUD concept is that every parent should give love to adolescent in order to get attachment with adolescent. After parental and adolescent attachment is formed, then parents are able to easily manage the lives of adolescent. Of course, parents should not impose their will because every adolescent has different characteristics, so this phase is called the understanding phase. Furthermore, when parents have got adolescent's hearts, able to manage adolescent well, and understand the characteristics of adolescent, then parents can not only suppress adolescent delinquency, but able to develop the potential of adolescent self.
\end{abstract}

Keywords: adolescent delinquency, parenting style, LOUD.

\section{Adolescent Delinquency}

Adolescent in a foreign language have a term, namely puberteit. Puberteit is a term that shows the phase of adolescence in Dutch, while the term is in Indonesian, which is puberty and has meaning as the nature of manhood. Adolescent are those aged 10-20 years, and saturation with changes in body shape and size, functional body, psychology and functional structures (Jafar 2005). According to Desmita, Ahmadi and Sholeh (2005) in Alfiasari, Latifah, and Wulandari (2011), adolescence is commonly used by experts between 12 and 21 years, consisting of 3 phases, early adolescents (ages 12 to 14), adolescence (ages 14 to 18), and late adolescence (age 18 to 21 years). According Purba (2014) opposition, rebellion, or dissent is a characteristic of adolescent who always confuse parents and family. In addition, adolescents also have the characteristics that symbolize a uniqueness, namely the proximity to a more dominant peer group with parents.

Adolescents are subjects who do not escape errors or mischief. According to Kartono (2010) in Sriyanto, Abdulkarim, Zainul, et al (2014), adolescent delinquency has psychic, interpersonal, interpersonal, and sociocultural nature. Then, adolescent delinquency is also divided into light mischief and delinquency that form heavy. In addition, the form of delinquency can also be divided into two, the mischief is done openly and secretly. This deliberately abandoned naughty mischief can be seen by others around him, for example, physical fights, rough- 
tongued like making fun of others in front of others, violating traffic lights, acts of violence, smoking, skipping school, and so on -other. In addition, unnecessarily unintelligible misbehavior is a delinquency that is done alone without anyone knowing it, such as watching porn videos in its own way, free sex, and others.

Studies on the forms of adolescent delinquency have been largely undertaken by researchers, resulting in quantitative data on adolescent delinquency symptoms that occur today. One study of adolescent delinquency ever conducted by Asyik, Ismanto, and Babakal (2015) in Soasio Village, Kota Tidore Kepulauan, found some adolescent often committed violence, skipping school, drinking, and free sex. That is, adolescent delinquency occurs not only in big cities or metropolitan, delinquent pleasure also in other cities without place status.

Research on adolescent delinquency was also done by Handayani, Herman, and Supardi (2009) mentioned as many as 1261 or $70.7 \%$ of late adolescents with marginal economic gologan characteristics, ages 18 to 23 consume alcohol. This study proves adolescent delinquency can occur in marginal economic groups. That is, the economic class is not a benchmark someone doing mischief.

Another adolescent delinquency that has been studied is delinquency associated with adolescent sex behavior. Utami (2015) found with $\mathrm{p}<\alpha$ for a dating experience of 0.038 to show that adolescent with dating experience had higher levels of sexual aggressiveness than those who did not have dating experience. Certainly the behavior of aggressiveness high sex will be the same sexual acts that have many types such as, petting, kissing, free sex, and others.

Based on the description of adolescent delinquency, it can be said adolescent delinquency in Indonesia does not know the status of residence, or economic status. It is an urgency to pay attention to mental-spiritual revolution at the adolescent level in order to minimize adolescent delinquency that can be done with the main indicator, that is parenting. The purpose of this paper is to enlarge the style of parenting and adolescent delinquency in Indonesia, and to describe the concept of authoritative parenting style LOUD (Loving, Organizing, Understanding, and Developing). Furthermore, literature studies on historical data on adolescent delinquency and childcare patterns in Indonesia, and the formulation of the concept of authoritative style LOUD parenting style with POAC analysis is the method of this name.

\section{Parenting Style}

Parenting is the process of providing the child's growth and development needs. Care is an effort in fostering, educating, directing, organizing children to meet every stage of development as well as physical, mental, psychological, social, moral, linguistic and spiritual development. Parenting is the process of nurturing and educating children from postpartum to children entering adulthood (Hastuti 2015). Processes in parenting will have an impact on applying parenting styles that parents give to children.

Parenting styles can be divided into four types namely, permissive, uninvolved, authoritative, and authoritarian. According to Hastuti (2015), high parenting style responsiveness, but low demandingness is called permissive, a low demandingness and low responsive force called uninvolved parenting, a low-style responsiveness, but high demandingness is called authoritative, while a high parenting style responsiveness and demandingness is called authoritarian. Parenting style permissive parents to children have the characteristics of parents giving high love to children, but little give the rules, lack of direction to the child, so this causes the lack of control to the child. Uninvolved parenting style is characterized by the absence of parental involvement in children, children are allowed to do as they please, tend to ignore the child, respond little to the child, and do not give love. Authoritative parenting style is a good type of parenting style and has parenting characteristics, that is the balance between giving rules, control, and discipline with the provision of affection, the formation of bonding and attachment to the child. An authoritarian parenting style is a nurturing style that has high control, rules, discipline, and punishment to children, so it is more restrained in children and tends not to have discussion with children in decision-making related to the child. The parenting style will affect the child's attitude and behavior. 
The result of statistic test from Abdulkarim's research, Sriyanto, Zainul, et al (2014) stated that the parenting pattern hypothesis has a significant positive effect on assertive behavior, while parenting pattern has a significant negative effect on adolescent delinquency tendency. Study results shows that parenting behavior and self-esteem are significantly correlated (Lestari 2008). Research conducted by Yulianto, et al (2014) states that there is a parenting relationship with the risk of violence in adolescents in Patrang Village, Patrang District, Jember District.

\section{The concept of LOUD (Loving, Organizing, Understanding, Developing}

The concept of LOUD is closely related to the rules or characteristics that exist in the authoritative style of parenting because it considers the balance between responsiveness and demanidngness, compassion and control, discipline and attention. LOUD negates the nature of rejection of parents against adolescents, whereas LOUD strongly emphasizes acceptance of parents to adolescents under any circumstances. This is done in order to create a harmonious interrelationship between parents and adolescents, so adolescent attachment to parents increases and parents can be a figure that can not be separated with the importance of peer group figure in the eyes of adolescent. According to Sofianita and Harti, when adolescent have more peer groups and often interact with peers will be very strong feel the presence of the group, so the behavior of peer groups will mean to him. On the other hand, it is different when the adolescent is more warmly interacting with the parent, then something will be the opposite, that is the behavior of the parent will mean for him to be imitated. According to Conger in Heaven \& Callan (1990) in Maentiningsih (2008), adolescents usually find good relationships with parents much more important when they get positive support and affection from parents so that adolescent are less dependent on their peers. On the other hand, LOUD's konesp only focuses on the care of early adolescents and middle adolescents.

The concept of LOUD is integrated with a management concept, namely POAC (Planning, Organizing, Actuating, and Controlling). The purpose of integration between the concept of LOUD and POAC, namely: (1) before the start of the first step in the form of giving love and love to the child (loving), then parents should make a planning that allows the purpose of loving conveyed to children exactly; (2) the organizing stage in the POAC concept goes into the loving stages of the LOUD concept. That is, every subject that is in the concept of LOUD circle, namely parents and adolescents must unite, coordinate, integrate, and work together in order to achieve the desired goal, namely the creation of adolescent who have emotional intelligence in minimizing mischief behavior; (3) The Actuating Phase in the POAC concept is at the organizing stage of the LOUD concept. This is because, the organizing stage of the LOUD concept means that the parent has done a higher stage than just giving love, which gives the rules to adolescents, discipline, and command; (4) the stage of controlling on the POAC concept is closely related to the developing stage. Controlling here means that parents are controlling the facilities that parents provide to adolescent.

\section{Planning Before Give Loving to Adolescent}

Planning is to prepare future activities by describing and formulating the activities necessary to achieve the desired results through goal setting, determining the allocation of resources and ways of achieving them (Darmawan and Ernawati, 2012). That is, at this stage parents should plan all forms of activities that can create adolescent adolescence with parents, such as: (1) minimum limit of intensity meeting with adolescent for a week. Parents should be able to meet with adolescent every day, so parents should plan for it; (2) quality time toward adolescent that describe the relationship of positive interaction of adolescent parents. Quality time can take the form of the intensity of eating together with the adolescent in a week, the amount of intensity of walking together with the adolescent in a month, the discussion with the adolescent, the celebration of a certain day. The more quality time with adolescent, the better.I 


\section{Loving}

Loving is an important factor in creating a quality nurturing to produce adolescents who have high competence in physical and emotional aspects, as expressed by (Maentiningsih 2008), this mature adolescent physically and emotionally can not be separated from the support and affection of parents in the form of secure attachment. Loving is a tenderness, warmth, secure attachment, and harmony that parents give to adolescent. According to Muntamah (2010), affection is a feeling of love or affection to a child. Loving means fulfilling all the needs of adolescents, accepting adolescent, supporting the presence of adolescent, listening actively to adolescent complaints, rewards and rewards for behaviors favored by parents.

Loving is closely related to interaction. According to Hastuti (2015), interactions that take place can be both verbal and non-verbal. Interactions in verbal communication include intonation, and word selection. Therefore, the interaction in positive verbal communication is that parents should be gentle, warm, and once firm, but should not snarl despite being angry with adolescent. Meanwhile, word selection should be a phrase that is easily understood by both adolescent and parents, as well as the selection of words to give a good appreciation or nickname to adolescent. An example of word selection is the word "dear" to give the nickname, "smart" or "diligent" or "great" to give a reward, "please" to ask adolescent to do something, "thank you" can be used when adolescent finish doing something that people old like, and "sorry" when parents feel guilty. Next, use communication with the word "I" instead of "you" to remind or symbolize disappointment. My communication to symbolize disappointment is meant not to intimidate adolescent or delegate all mistakes to adolescent. Examples of my communication, "I am to blame for your parenting, so as to create bad deeds you do" or "I really hope that you will become a better person and not make the same mistakes."

Interactions in verbal communication should be integrated in the parent's non-verbal communication pattern. Non-verbal interactions can be gestures, facial or facial expressions, parental actions and behaviors (Hastuti 2015). Non-verbal positive interactions by parents through gestures include touching an adolescent with warmth, hugging an adolescent, and kissing adolescent. Then, the expression or facial expression is to make the face look warm, pleasant, and not in a very stressful situation even in a state of anger such as, smiling face, enlarged pupils or sparkling when in ordinary interaction, grief and disappointment face in anger, and did not put a bulging eye and lips contracted in anger. Furthermore, the actions and behaviors of parents are characterized by the fulfillment of all the needs of adolescents, exemplifying adolescents of good deeds, facilitating adolescents in developing their interests and talents, adapting to the characteristic forms and adolescent tempraments.

\section{Organizing}

Parents will be easier in organizing or managing adolescent when they have created good bonding and attachment to adolescent from the loving process that has been done. Organizing stage is done as a form of actuating to prevent adolescent delinquency, so that in this stage parents and children should be able to cooperate. That is, when parents have a rule and control to adolescents, as well as performing the formation of selfcompetence, then the adolescent should be happy and accept it. Hastuti (2015) mentions that parents need some conditions to take care of adolescent, namely: (1) adapt to physical changes in adolescents; (2) establishing the confidence and positive attitude of adolescents; (3) establishing self-control and emotion in adolescents; (4) establishing healthy life behavior in adolescents and relationships with peer groups; (5) provide supervision including how to socialize with friends and handle adolescent who have peer pressure; (6) establishing independence and avoiding conflict with adolescents; (7) establish consistent and clear rules to adolescents. For example, about the last boundary of the adolescent can come out at night, the condition of a adolescent can go out at night, whether this condition depends on other factors, such as youth activity the next day, adolescence, geographical location, and adolescent friends. In addition, the implementation of organizing stage can also be done by establishing good eating patterns for adolescent, namely nutritious, diverse, and balanced. 


\section{Understanding}

Every adolescent born has the right to be a concern for every parent to be able to prevent delinquency of adolescent, especially adolescents by providing stimuli such as how to understand, love, and develop the potential of adolescents in particular. Thus, in the organizing stage as previously described, parents can not necessarily regulate the youth, and discipline the adolescent in certain ways as he wishes, but parents should know the rights of adolescent in particular. On the other hand, there is one thing parents must understand, which is not to give rough parenting to adolescent. Conger's research in Hastuti (2015) mentions that adolescents who are involved in drug addiction, drinking alcohol, and engaging in gang fights are children who are roughly nursed or called harsh and strict parenting.

The child is essentially an obligation and responsibility for parents is certainly an excuse for parents to fulfill their rights. According to the UN International Convention 1989 article 27, every child has the right to an adequate standard of living for the physical, social, mental, spiritual and social development of the child's emotions. Then, according to Hastuti (2015), in 1959 the United Nations issued a declaration which is the second international declaration on the rights of children and there are 10 things to note: (1) children should be raised by their parents and adults; (2) children should be fed according to their needs; (3) child health and development should take precedence; (4) the child shall have a reasonable place of shelter; (5) the child must be able to at least primary education; (6) the child must receive training and education according to his or her talents and abilities; (7) children should thrive in order to enjoy life; (8) the child should be given an opinion opportunity; (9) the child must have access to basic services; (10) the child must obtain information and be protected by rights and interests.

\section{Developing}

Development of interest and potential of children is an investment for parents to adolescents to create adolescents who have high competence and able to prevent or minimize adolescent delinquency. Furthermore, the development of interests and potential of children must be supported by several factors, namely environmental factors. According to the theory of ecological systems initiated by Bronfenbrenner who is a child expert. According to Bronfenbrenner the life environment of a child is influenced by several environmental systems consisting of microsystems, mesosystems, macrosystems, ecsosystems, and chronosysstem. At this stage of development, at least parents provide facilities for child development on microsystems and mesosystems.

Microsystems are the closest environment to adolescent, directly interacting with children, and profoundly affecting adolescent growth. Microsystems consist of family environment, neighboring environment, friendship environment or peer group. That is, in developing the potential and talent of adolescents, then parents should provide the best facilities in this environment. Parents should provide a good parenting climate and provide harmony in the family. Furthermore, parents should also provide a good home or neighborhood environment which means in the election temoat stay, parents should pay attention to the good or bad quality of the neighborhood. Then, parents should introduce adolescents to a good peer group environment and monitor the peer group's environment. The better the quality of microsystems received by adolescent, the more it will affect adolescent grow in a positive direction. Furthermore, the placement of the microsystem that must be attached to the child is the school environment, the course environment. Developing the interest and potential of adolescent means that parents facilitate adolescents to go to school in a place of good quality. Then, parents should support adolescent interests and potential by channeling them to a training ground or course, examples of martial arts courses, swimming, painting, dancing, and so on. On the other hand, the mesosystem also affects adolescent because it is the interaction relationship between the parent and the subject residing in the child microsystem. For example, relationships between parents and adolescent teachers at school as well as parent relationships with youth teachers in the course. Keeping adolescent excited about developing their potential and interests means 
maintaining good relationships between parents and subjects that interact directly with adolescent such as schoolteachers, tutors, adolescent peer groups, and others.

\section{Conclusion}

Adolescent delinquency can be minimized by good parenting, balancing between giving love with control, rules, and discipline. Such parenting is called the authoritative parenting style that enters into the concept of LOUD (loving, organizing, understanding, and developing). Loving focuses on the provision of affection to adolescent depicted by both verbal interaction (good speech and soft tone) and non-verbal (hugs, kisses, swabs, and adolescent needs). Organizing is closely related to the application of parental roles in disciplining and managing adolescent-related peer groups, establishing self-confidence, and healthy living behaviors, and giving rules. Understanding is a must for parents to understand the rights of adolescents. Developing is a form of parental obligation to facilitate matters relating to the development of interests and potential of adolescents.

\section{Suggestion}

The concept of LOUD (loving, organizing, understanding, and developing) authoritative parenting style is still an idea of how to minimize Adolescent delinquency that has not been tested, so it has no validity. Therefore, this concept should be investigated further in the future for the validity process. Then, the concept of LOUD authoritative parenting style should still be developed by pursing the bound variables shaped Adolescent delinquency.

\section{Acknowledgements}

Thanks to all those who have helped in completing this paper, such as Allah SWT, family, professors, and friends. Without assistance from related parties, this paper will not be able to be completed. The authors are also grateful to the Conference Coordinator for organizing the 8th International Conference on Literature, Languages, Humanities and Interdisciplinary Studies (LLHIS-17) on December 14-15, 2017 at Kuala Lumpur (Malaysia).

\section{References}

[1] A. Abdulkarim, A. Zainul, Sriyanto, dkk, "Perilaku Asertif dan Kecenderungan Kenakalan Remaja Berdasarkan Pola Asuh dan Peran Media Massa,” Jurnal Psikologi, vol 41, pp. 74-88, Juni 2014.

[2] A.D. Purba, "Dampak Kenakalan Remaja Dalam Perspektif Kriminologi Di Kota Medan," Jurnal. Fakultas Hukum., Univ., Sumatera Utara, Indonesia, 2005.

[3] Alfiasari, M. Latifah, A. Wulandari, "Pengasuhan Otoriter Berpotensi Menurunkan Kecerdasan Sosial, Self-Esteem, dan prestasi akademik Remaja," Jurnal Ilmu Keluarga dan Konsumen, vol. 4, pp. 46-56.

[4] D. Darmawan, Ernawati, "RENCANA STRATEGIS PELAYANAN PERIZINAN," Jurnal Administrasi Pembangunan, vol. 1, pp. 1-100, November 2012.

[5] D. Hastuti, “Gaya Pengasuhan,” in Pengasuhan : Teori, Prinsip, dan Aplikasinya di Indonesia,”Bogor: IPB Press, 2015, pp. 138-139.

[6] D. Hastuti, "Interaksi Antara Anak, Orang Tua, dan Masyarakat," in Pengasuhan : Teori, Prinsip, dan Aplikasinya di Indonesia,"Bogor: IPB Press, 2015, pp. 59-60

[7] D. Hastuti, "Pengasuhan Menurut Tahapan Usia Anak," in Pengasuhan : Teori, Prinsip, dan Aplikasinya di Indonesia,"Bogor: IPB Press, 2015, pp. .

[8] D. Hastuti, "Pengertian Pengasuhan Anak," in Pengasuhan : Teori, Prinsip, dan Aplikasinya di Indonesia,"Bogor: IPB Press, 2015, pp. 55.

[9] D. Hastuti, "Prinsip dalam Kebijakan untuk Anak Melalui Penguatan terhadap Kapasitas Pengasuhan (Parenting)," in Pengasuhan : Teori, Prinsip, dan Aplikasinya di Indonesia,”Bogor: IPB Press, 2015, pp. 354. 
[10] D. Hastuti, Dampak Gaya Pengasuhan,“ in Pengasuhan : Teori, Prinsip, dan Aplikasinya di Indonesia,"Bogor: IPB Press, 2015, pp. 149.

[11] D. Maentiningsih, "Hubungan Antara Secure Attachment Dengan Motivasi Berprestasi Pada Remaja," Dept. Psikologi, Univ., Gunadarma, Indonesia, Maret 2008

[12] F. M. Asyik, A.Y. Ismanto, A. Babakal, "Hubungan Pola Asuh Orang Tua Dengan Kecerdasan Emosional Pada Anak Usia Remaja Dikelurahan Soasio Kota Tidore Kepulauan, “E-Journal Keperawatan, 3(2).

[13] I.T. Utami , "Gambaran Agresivitas Perilaku Seksual Remaja Putra SMA di Jakarta Selatan," Wacana Kesehatan, vol 1, pp. 1-49, December 2015.

[14] Jafar N, "Pertumbuhan Remaja," Dept. Ilmu Gizi, Fakultas Kesehatan Masyarakat, Universitas Hasanuddin, Indonesia, 2005, pp. 1.

[15] Konvensi Tentang Hak-Hak Anak, Majelis Umum Perserikatan Bangsa-Bangsa, November 1989.

[16] Muntamah, "Hubungan Antara Kasih Sayang Orang Tua Dengan Motivasi Belajar ( Studi Kasus Pada Siswa Sd Negeri Lebak Kecamatan Bringin Kabupaten Semarang Tahun 2010),” Dept. Pendidikan Agama Islam, Sekolah Tinggi Agama Islam Negeri, Indonesia, 2010.

[17] R.S. Handayani, M.J. Herman, S. Supardi, "Pola Konsumsi Miras Dl Kalangan Anak Dan Remaja Golongan Ekonomi Marginal,” Buletin Penelitian Sistem Kesehatan, vol. 12, pp. 313-318, July 2009.

[18] S. Lestari, "Pengasuhan Orang Tua dan Harga Diri Remaja: Studi Meta Analisis,” Indonesian Psychological Journal, vol. 24, pp. 17-25, 2008.

[19] Yulianto, et al. (January 2012), "Hubungan Pengasuhan Orang Tua dengan Risiko Tindak Kekerasan pada Remaja di Kelurahan Patrang Kecamatan Patrang Kabupaten Jember (The Correlation of Parenting with Risk of Juvenile Violent in Patrang Village District Patrang Jember,” E-Jurnal Pustaka Kesehatan [online]. 2 (1). 